\title{
Corporate Social Responsibility and Financial Performance:
}

\section{A non-linear and disaggregated approach.}

\author{
Joscha Nollet $^{1}$, George Filis ${ }^{2}$, Evangelos Mitrokostas ${ }^{3}$
}

\begin{abstract}
The present paper examines the relationship between Corporate Social Performance (CSP) and Corporate Financial Performance (CFP), using both accounting-based (Return on Assets and Return on Capital) and market-based (Excess Stock Returns) performance indicators. We use Bloomberg's Environmental Social Governance (ESG) Disclosure score covering the S\&P500 firms in the period 2007-2011 which allows for the examination of both linear and nonlinear relationships to be considered. The results of the linear model suggest that there is a significant negative relationship between CSP and Return on Capital. However, the non linear models provide evidence of a U-shaped relationship between CSP and the accountingbased measures of CFP, suggesting that in the longer run CSP effects are positive. Most prominent among our results is that fact that by disentangling the ESG Disclosure score into its environmental, social and governance sub-components, we find that a U-shaped relationship exists only between the governance sub-component and CFP. A straightforward implication of our findings suggests that in order for CSR to serve the interests of the shareholders, a long-run planning and considerable resources should be dedicated at this direction, given that CSR expenditure pays off only after a threshold of CSP has been reached. Furthermore, the fact that governance is the key driver affecting the CSP-CFP relationship suggests that CSR investments should be directed to this component.
\end{abstract}

Keywords: Corporate Financial Performance; Corporate Social Performance; Environmental Social Governance Disclosure score; Governance.

Acknowledgments: The authors would like to thank the editor, Prof. Sushanta Mallick and four anonymous referees for their useful comments and suggestions which helped us to improve the scope and clarity of the paper. The authors would also like to thank Mrs Mina Dragouni for her contribution. Financial support by the Portsmouth Business School, Research Project Fund 2013 is gratefully acknowledged. The authors are solely responsible for any remaining errors and deficiencies.

\footnotetext{
${ }^{1}$ European Parliament, ASP 15 E 240, Rue Wiertz 60, 1047 Brussels, Belgium.

2 Department of Accounting, Finance and Economics, Bournemouth University, Executive Business Centre, 89 Holdenhurst Road, BH8 8EB, Bournemouth, UK.

${ }^{3}$ Corresponding author: Economics and Finance Subject Group, Portsmouth Business School, University of Portsmouth, Richmond Building, Portland Street, Portsmouth, Hampshire, PO1 3DE, UK. Tel: +44 (0) 2392844133, email: evangelos.mitrokostas@port.ac.uk.
} 


\section{Introduction}

The business case for corporate social responsibility, "a concept whereby companies integrate social and environmental concerns in their business operations and in their interaction with their stakeholders on voluntary basis" (European Commission, 2001, p.6) is debated extensively in academia and board rooms as a highly relevant topic, particularly in the aftermath of the financial crisis. "In recent years business increasingly has been viewed as a major cause of social, environmental, and economic problems. Companies are widely perceived to be prospering at the expense of the broader community." (Porter and Kramer, 2011, p.4). Hence, authorities, Non-Governmental Organizations (NGOs) and consumers have called for a more responsible and sustainable way of doing business. However, the decisive question that has to be answered for shareholders in a business context is whether CSR serves a company's financial performance.

Recent literature appears to be rather inconclusive with respect to the question of whether corporate social responsibility performance (CSP) can be translated in positive corporate financial performance (CFP). While a positive consensus seems to appear (Margolis et al., 2009), yet, this consensus is still fragile, since a range of recent studies support for either negative (Mittal et al., 2008) or mixed results (Schreck, 2011). Most research in this field heavily relies on the dataset provided by Kinder, Lydenberg and Domini (KLD) (see, inter alia, Andersen and Dejoy, 2011; Jiao, 2010; Callan and Thomas, 2009; Brammer et al., 2009; Becchetti and Ciciretti; 2006; Hillman and Keim, 2001; McWilliams and Siegel, 2000). Yet, according to Margolis et al., (2009) alternative measures CSR performance should also be considered in the literature.

Furthermore, most research making use of the KLD dataset only test for a linear relationship between a firm's corporate social performance and its financial performance. However, recent developments in microeconomic theory rather suggest a non-linear set up 
(see for instance; Manasakis et al., 2013, 2014; Garcia-Gallego and Georgantzis, 2009). A non-linear relationship between CSP and CFP is therefore in line with economic intuition, but has rarely been tested at all (see, for instance, Barnett and Salomon, 2012, 2006). As in Barnett and Salomon $(2012,2006)$ we consider that those firms which voluntarily engage in more socially responsible activities incur higher corresponding costs, therefore firms with higher CSP score in the index have invested more financial resources in CSR comparing to those firms with lower CSP.

In addition, measuring corporate social responsibility has proven to be quite difficult since it is a multidimensional concept covering a whole set of different areas (Waddock and Graves, 1997). Those areas range from stakeholder management issues (such as employees' working conditions) and environmental concerns up to patronage of arts and culture. As firms tend to use CSR as a means for public relations they often apply a very broad definition of CSR. Hence, alternatives to KLD third-party auditors' data set need also to be considered in order to assess whether the current results of the literature are robust to different datasets.

Given these gaps in the literature, the main contributions of the present paper can be described succinctly. First, motivated by the works of Barnett and Salomon (2012, 2006), we examine both the linear and non-linear relationship between CSP and CFP, yet under the context of a new dataset, namely Bloomberg's Environmental Social Governance (ESG) Disclosure score. Bloomberg's score covers the S\&P500 firms for the period 2007-2011 and serves as a proxy for actual CSR performance. The ESG score has the benefit of being easily transformable into a quadratic score. Second, we extend this line of research by disentangling the ESG Disclosure score into its three components so that we can identify the key driver of CFP. In particular, we disentangle the ESG Disclosure score into environmental, social and governance sub-components. Third, this study examines the effects of CSP on CFP using 
both accounting-based (Return on Assets, Return on Capital) and market-based (Excess Stock Returns) performance indicators, for robustness purposes.

In short, our results of the linear model suggest that there is a negative relationship between CSP and CFP, although this is significant only in the case of the Return on Capital. However, when a non-linear model is used, we find evidence of a U-shaped relationship between CFP and the accounting-based measures of CFP, i.e. Return on Assets and Return on Capital. The results do not allow us to report any significant relationship between CSP on market-based CFP, i.e. Excess Stock Returns. This U-shaped relationship confirms the findings by Barnett and Salomon (2012), who were the first to establish such a relationship by using a normalised version of the KLD dataset. This finding implies that CSR engagement does not pay off immediately, but only after a crucial point of CSR investment is crossed. While in the beginning additional CSR engagement affects profitability negatively, this effect reverses at some point and ultimately serves a company's profitability.

Most prominent among our findings is the fact that disentangling the ESG score into its sub-components, we find that only governance exhibits a significant U-shaped relationship with CFP. By contrast, no significant relationships can be reported for environmental and social sub-components. This finding has not been previously reported and adds on the discussion regarding the Stakeholder Influence Capacity (SIC) as introduced by Barnett (2007). SIC suggests that stakeholders will only perceive some of the firms as credible CSR actors and therefore reward them for their activities. Our results propose that CSR activities related to improvements in governance will initiate stakeholders' positive reaction to the firm's CSR activities. This is in line with a recent strand of the literature that suggests that governance related CSR by firms acts as a credible commitment of firms towards CSR. Therefore, it may boost the positive demand effects from the socially conscious consumers 
and in turn the financial performance of the firm (See for instance, Lambertini, L. and Tampieri, 2015; Becchetti et al. 2014; Manasakis et al., 2014; Kopel and Brand, 2012).

The remaining of the paper is structured as follows. Section 2 reviews the literature and Section 3 presents the data and the panel regression model. Section 4 analyses the effects of Corporate Social Performance on Corporate Financial Performance, before Section 5 concludes the study.

\section{Review of the relevant literature}

The theoretical discussion of good corporate citizenship has evolved tremendously since Milton Friedman's famous and outright rejection of CSR in 1970. Friedman argued that "the social responsibility of business is to increase its profits" (p. 1) and that appointed managers have no right to spend shareholders' money for other purposes than maximizing shareholder return. In fact, agency theory suggests that insiders, i.e. managers, have incentives to over-invest in CSR to increase their personal reputation (Barnea and Rubin, 2010). This line of thought (shift of focus hypothesis) suggests that increasing CSR expenditure will lead to deteriorating profits as managers are distracted from their main objective.

Yet, the theoretical framework suggested by Friedman is not conclusively supported by theory or by empirical evidence. A lot of convincing arguments have been made of how a good CSR performance as a strategic investment could eventually translate into higher profits and thus higher shareholder value. Jensen calls this idea "enlightened value maximization" (2001, p. 308) and stresses that a firm's value development should be regarded as the single criterion to assess the management's success. Nonetheless, he acknowledges that taking into account different stakeholders interests may be a legitimate and effective means to achieve this objective. This kind of "strategic CSR" is consistent with the strategy chosen by a profit- 
maximizing firm (Baron, 2001, p. 9). In fact, this idea is an advanced version of the original stakeholder theory as proposed by Freeman (1984). However, strategic investments with respect to CSR have the power to influence the competitive context of a company in a favorable way (Porter and Kramer, 2002, p. 61). Examples of such investments are: managing risk and reputation, human resource management, better access to finance, cost savings due to efficiency improvements and avoiding regulation (see, Reinhardt et al., 2008; Cochran, 2007; Heal, 2005; Greening and Turban, 2000, among others). In line with the above we introduce the assumption of Barnett and Salomon $(2012,2006)$ considering that firms with higher CSP score in the index have invested more financial resources in CSR comparing to those firms with lower CSP.

Given the above, Russo and Fouts (1997) have identified CSR as a source of competitive advantage in accordance with the resource based view of the firm. According to this theory, firms need to possess resources that are valuable, rare, imperfectly imitable and not substitutable in order to create a sustainable competitive advantage (Barney, 1991). McWilliams and Siegel (2011) argue that some of the CSR investments outlined above, namely brand reputation, human capital (including top management) and the easier availability of finance, are exactly such resources and are created by CSR measures. Hence, engaging in corporate social responsibility issues could be a worthwhile consideration for a firm's management.

Although the body of empirical literature on the CSP-CFP link is vast, it remains inconclusive. There are studies reporting positive, negative as well as neutral relationships between CSP and CFP (Fernandez-FeijooSouto, 2009). More recently a fragile consensus seems to emerge. Recent meta-analysis of 167 studies from 1972 to 2007 conducted by Margolis et al. (2009) suggests that there is a positive effect of CSR on accounting-based as well as market-based profits. However, despite this overall trend, there remains a range of 
recent literature finding either negative (Mittal et al., 2008) or mixed results (Schreck, 2011). McWilliams et al. (2006) trace inconclusive results back to rather technical causes claiming that diverging empirical results may be due to inconsistencies in the definition of the dependent and independent variables, different samples or poor research design. In fact, many studies rely on similar data and a similar measure of corporate social performance, namely the KLD indicator (Margolis et. al, 2009). Apparently, this has consequences for the research design as well and most analysis has been only linear so far.

Baron (2001) argues for better taking into account the kind of CSR a firm engages in. While strategic CSR investments are likely to have a positive impact on profitability, altruistic CSR may have the reverse effect. Hillman and Keim (2001) tested this argument empirically by subdividing corporate social performance into stakeholder management and social issues. This division follows Baron"s (2001) definition of "strategic" and "altruistic" CSR. Regressing those two variables against the shareholder wealth creation, they find opposing effects. More specifically, they find that while stakeholder management is positively correlated with shareholder wealth creation, engagement in social issues has negative effects. The authors argue that those opposing effects "may partially explain why aggregating the two together into a measure of corporate social performance may lead to ambiguous results" (Hillman and Keim, 2001, p. 136). However, as McWilliams and Siegel point out (2011), although this distinction is elegant in theory, in practice it is usually hard to account for. This is because composite index numbers often aggregate different kinds of CSR activities into one single score.

The financial crisis of 2007-2009 has affected the business environment and society's expectations regarding the relationship of business and society markedly. Whether this had an impact on the link between corporate social performance and corporate financial performance has been rarely tested. Again, two competing effects are conceivable. On the one hand, there 
is reason to assume that the demand of socially responsible manufactured goods (or CSR as a product attribute) is income elastic. Portney (2008) argues that the shape of the "Environmental Kuznets Curve" (EKC) gives some evidence for this notion. The key idea is that people care more about environmental issues in line with rising income. The same is likely to hold true for CSR. Assuming that CSR has a positive income elasticity (i.e. being a normal good) or even an income elasticity greater than one (i.e. being a luxury good), in times of recession and declining real income, the demand for CSR goods (or goods and services with CSR attributes) should go down. At the same time, companies facing declining sales and profits feel the need to slash their budgets. In times companies lay off staff, cut back on benefits and pension schemes discretionary expenditure such as CSR spending would be an easy target. Indeed, The Economist (2009) reports that non-strategic CSR spending such as corporate philanthropy is often among the first expenditure items to be ceased.

The role of governance is also important. Poor corporate governance, i.e. a lack of corporate social responsibility, is widely regarded as one of the key sources of the financial crisis. As many people are disappointed about how big business has been done for quite some time, pro-social behavior and business ethics of firms could become an even bigger issue for consumers, investors and regulators. Managers are likely to be responsive to those demands "focusing on a wider concept of entrepreneurial profit with a long term view and giving the proper importance to stakeholders" (Fernandez-FeijooSouto, 2009, p. 41). Although, inferential analysis is still lacking, surveys amongst senior decision makers (Harwood et al., 2011) as well as media analysis of the media discourse (Ellis and Bastin, 2011) has proven corporate social responsibility to be quite resilient.

Given the aforementioned literature, we posit the following hypotheses: 
Hypothesis 1: There is a linear and positive effect of the Corporate Social Responsibility performance on Corporate Financial Performance.

Hypothesis 2: There is a linear and positive effect of the Environmental performance on Corporate Financial Performance.

Hypothesis 3: There is a linear and positive effect of the Social performance on Corporate Financial Performance.

Hypothesis 4: There is a linear and positive effect of the Governance performance on Corporate Financial Performance.

Hypothesis 5: The positive effects of total CSR performance, as well as, the Environment, Social and Governance performances on Corporate Financial Performance are not linear.

\section{Data Description and Methodology}

\subsection{Data description}

This paper investigates the effects of corporate social performance (CSP) on corporate financial performance (CFP) taking into account both linear and non-linear relationships. The sample consists of annual data for all firms listed in the S\&P500 stock market index during the period 2007-2011 and all data used are obtained from Bloomberg.

More specifically, we use two ratios to access the firms' financial performance, based on accounting measures, namely Return on Assets $(R o A)$ and Return on Capital $(\operatorname{RoC})$. In addition, we use annual excess stock returns (Ex. Stock Returns) as a measure of marketbased firms' financial performance. CSR performance, which is the key independent 
variable, is approximated by the Bloomberg's ESG Disclosure score, which is based on publicly available company material and covers a wide range of data from $\mathrm{CO}_{2}$ emissions to the share of women on the board (Bloomberg, 2013, p. 16). ${ }^{4}$ The scoring system ranges from full disclosure with a score of 100 to null disclosure with a score of 0 and is therefore a measure of breadth of reporting. (See also Eccles et al., 2011). The ESG score can be directly squared in order to be used in a non-linear setting, as opposed to the KLD score, which ranges from -2 to +2 and thus it requires some normalisation (see, for instance, Barnett and Salomon, 2012).

Apart from the ESG Disclosure score, we also consider firms' leverage ratio (which serves as a proxy for Risk), sales revenue (Sales) and research \& development expenditure $(R \& D)$. The leverage ratio, sales revenue and research \&development expenditure, serve as control variables. The choice of the control variables can be justified by recent studies that find firm size (turnover), risk (measured by the total debt to total assets ratio) and research and development expenditure to be essential control variables when assessing the effects of CSP on CFP (Anderson and Dejoy, 2011; Margolis et al., 2009; McWilliams and Siegel, 2000). Finally, we include a dummy variable (Crisis), which takes the value of 1 during the Great Recession period (i.e. 2007-2009) and zero otherwise.

Given that CSR is a multidimensional concept and effects of one dimension sometimes cancels out opposing effects of another dimension, it is advantageous to have disaggregated data available (Margolis et al., 2009; Brammer et al., 2009). Thus, in this study we disaggregate the ESG Disclosure score into its three sub-components, namely, the environmental performance $(E N V)$, social performance $(S O C)$ and governance performance

\footnotetext{
${ }^{4}$ The Bloomberg's ESG score by construction considers sustainability and ethical impacts of an investment within a company; therefore it is directly related to spending of financial resources in specific CSR areas (Bloomberg, 2013).
} 
$(G O V) .{ }^{5}$ This disaggregation provides us with the advantage to assess which CSR component is the key driver for improving CFP.

It is worth noting that despite the aforementioned advantage of the ESG Disclosure score, this dataset has not been widely used in the literature, given the fact that the score is available since 2009 (though containing some retrospective data). Thus, our study aims to provide new insights regarding the effects of CSP on CFP using this new score.

Table 1 provides some descriptive statistics of our variables, whereas Table 2 presents the unconditional correlations. Table 1 reveals that the ESG sub-components have some distinct difference. For instance, $S O C$ score has the lowest average value, whereas the highest mean is observed for $G O V$. Furthermore, $G O V$ is fairly stable, as this is shown by its standard deviation, while $S O C$ is fairly volatile. Furthermore, another notable observation that we can deduce from Table 1 is the fact that the three measures of firm's performance also provide a somewhat different behavior. Ex. Stock Returns exhibit the highest volatility, given its standard deviation, as well as, its minimum and maximum values. By contrast, $R o C$ is the least volatile firm's performance indicator. Finally, Sales and $R \& D$ also exhibit considerable volatility. We further notice that the $R o C$ mean value is considerably higher compared to both the RoA and Ex. Stock Returns.

\section{[TABLE 1 HERE]}

The unconditional correlations in Table 2 suggest that our variables are not highly correlated among them. The highest correlations are observed among ESG and its subcomponents, although their correlations do not raise concerns for any multicollinearity

\footnotetext{
${ }^{5}$ In order to avoid any confusion the ESG score considers governance performance that is related to CSR. More specifically Bloomberg's ESG score by construction considers sustainability and ethical impacts of an investment within a company. The governance score in particular considers CSR oriented issues such as: "internally developed statements of mission or values, codes of conduct, and principles relevant to economic, environmental, and social performance and the status of their implementation", "externally developed economic, environmental, and social charters, principles, or other initiatives to which the organization subscribes or endorses" and "key topics and concerns that have been raised through stakeholder engagement, and how the organization has responded to those key topics and concerns, including through its reporting" (Bloomberg, 201, p74-75).
} 
issues. ${ }^{6}$ An interesting observation that can be made from Table 2 is the fact that the marketbased performance indicator (Ex. Stock Returns) is marginally positively correlated with the accounting-based performance indicators of $\operatorname{RoA}$ and $\operatorname{RoC}$. This suggests that excess stock returns are impact by other factors apart from firms' fundamentals. Furthermore, we notice that $E S G$ score, as well as, its sub-components are positively correlated with the performance measures. This is a first indication that higher scores may lead to better performance. In addition, we observe that risk is negatively correlated with all performance measures. A final interesting observation from Table 2 is the fact that Sales are not positively related to $R o A$ and Ex. Stock Returns.

\section{[TABLE 2 HERE]}

Tables 3and 4 provide some further descriptive statistics of the ESG score, along with its sub-components, over the study period. From Tables 2 and 3 we observe that during the period 2007-2010 an upward trend is observed in the ESG score (improving from 22.3 to 26.9), as well as, in all its sub-components. This upward trend is intercepted in 2011 for the $E S G$ score and the $G O V$ sub-component, when a small decrease is evident. The fact that the ESG disclosure score (and its sub-components) constantly increase over the study period indicates that CSR commitment is quite resilient over time. This holds even for turbulent times (i.e. during the Great Recession of 2007-2009), given that no sharp drop in the ESG score can be reported. A notable observation is that that despite the fact that the ESG score and the $E N V$ and $S O C$ sub-components exhibit a relatively high variance (as shown by the standard deviation values) among the S\&P500 firms, this does not hold for the GOV subcomponent. This is suggestive of the fact that listed firms in the S\&P500 may have different

\footnotetext{
${ }^{6} \mathrm{We}$ have also tested for multicollinearity is our models using the VIF and the results suggest that our models do not suffer from multicollinearity. The results are available upon request.
} 
agenda in terms of environmental and social performance but they share very similar governance performance.

[TABLE 3 HERE]

[TABLE 4 HERE]

\subsection{Panel regression model}

This section describes the method used to examine the effects of CSP on CFP. More specifically, a panel regression model is employed for this study. Our panel regression model is as follows:

$$
y_{i t}=\alpha_{0}+\beta_{1} C S R_{i, t-n}+\beta_{2} \mathbf{x}_{i, t-n}^{\prime}+\beta_{3} D_{t}+\varepsilon_{i, t}, \text { for } i=1,2, \ldots, K \text { and } n=0,1, \ldots, N
$$

where, $y_{i, t}$ is the corporate financial performance indicator (i.e. RoA, RoC and Ex. Stock Returns, depending on the specification) for firm $i$ at time $t$ and $C S P_{i, t-n}$ is the corporate social responsibility score (in both contemporaneous and lagged terms), which, depending on the specification, is either the ESG score or its three sub-components (SOC, ENV, GOV). $\mathbf{x}_{i, t-n}=\left[\right.$ Risk $_{i, t-n}$, Sales $\left._{i, t-n}, R \& D_{i, t-n}\right]$ 'is the a vector which includes the control variables in contemporaneous and lagged terms. $\alpha_{0}$ represents the constant term and $D_{t}$ is a dummy which captures the effects of the Great Recession of 2007-2009 (and takes a value of 1 for the years 2007, 2008 and 2009 and zero otherwise). The $\varepsilon_{i, t}$ terms contains both the idiosyncratic error term $u_{i, t}$ and $c_{i}$ which controls for the unobserved firm and time effects, such that $\varepsilon_{i, t}=u_{i, t}+c_{i}$. In our case, we use time and firm fixed effects. So, Equation 1 takes the following form: 


$$
\begin{gathered}
y_{i, t}=\alpha_{0}+\beta_{1} \operatorname{CSR}_{i, t-n}+\beta_{2} \mathbf{x}_{i, t-n}^{\prime}+\beta_{3} D_{t}+u_{i, t}+c_{i}, \text { for } i=1,2, \ldots, K \text { and } n=0,1, \ldots, N \\
E\left(u_{i, t} \mid C S R_{i}, \mathbf{x}_{i}, c_{i}\right)=0 \\
\operatorname{Var}\left(u_{i, t} \mid C S R_{i}, \mathbf{x}_{i}, c_{i}\right)=\operatorname{Var}\left(u_{i, t}\right)=\sigma_{u}^{2} \text { for all } t=1,2, \ldots, T \\
\operatorname{Cov}\left(u_{i, t}, u_{i, s} \mid C S R_{i}, \mathbf{x}_{i}, c_{i}\right)=0 \text { for } t \neq s .
\end{gathered}
$$

In this paper we extend the linear relationship between CSP and CFP of Eq. 1 in order to incorporate a quadratic relationship, given that the aforementioned relationship may exhibit a U-shape.

$y_{i t}=\alpha_{0}+\beta_{1} C S R_{i, t-n}+\beta_{2} \operatorname{CSR}_{i, t-n}^{2}+\beta_{3} \mathbf{x}_{i, t-n}^{\prime}+\beta_{4} D_{t}+e_{i, t}$, for $i=1,2, \ldots, K$ and $n=0,1, \ldots, N$

The results are presented in Section 4.

\section{Empirical Findings}

Table 5 reports the panel regression results for the effects of ESG score on CFP. Specifications (1)-(3) report the linear relationship between ESG and the three CFP indicators (RoA, RoC and Ex. Stock Returns).

\section{[TABLE 5 HERE]}

Results suggest that in linear specifications the effect of CSR performance is positive but insignificant for all measures of CFP. Furthermore, the lagged ESG coefficient is negative but not significant, as well. Therefore, we maintain that we cannot confirm Hypothesis 1. Overall, this result is not in line with other studies, which suggest that a significantly positive effect of corporate social performance on CFP (see, for instance, Margolis et al., 2009). Nevertheless, these results partially confirm the findings by Fernandez-FeijooSouto (2009) and Mittal et al. (2008), among others.

Furthermore, the results for the control variables are as expected. More specifically, CFP is significantly affected by Risk (negatively), Sales (positively) and $R \& D$ (positively). Intuitively, while excessive risk drives down CFP, the opposite is true for research and 
development. The Crisis dummy coefficient is negative and significant, signifying the negative effect of the Great Recession on CFP. The lagged dependent variables are positive for $R o A$ and $R o C$, whereas a negative coefficient is observed for Ex. Stock Returns. Potentially the latter finding captures the declining trend of stock prices during the study period.

We now turn to the CSP-CFP link in quadratic models for all three performance indicators (see, Table 5, specifications (4)-(6)). The quadratic models reveal some rather interesting results. We find that for both $R o A$ and $R o C$, there is a significant U-shaped CSPCFP relationship, whereas the effect of CSP on Ex. Stock Returns is insignificant. Intuitively, the negative effect of CSP on CFP in the linear model turns out to be part of a more complex relationship that is only revealed when testing for non-linear models. The U-shaped relationship discovered between CSP and accounting-based CFP measures (i.e. $R o C$ and RoA) implies that investment in CSR does not pay off immediately, but rather only after a threshold level of CSP is reached. This finding provides evidence in favour of our Hypothesis 5, which suggest that a non-linear relationship exists between CSP and CFP. Apparently, improving CSP is a costly procedure and requires a vast amount of resources in order to transform the supply chain of the firm (Manasakis et al., 2013; Porter and Krammer 2011; Reinhard and Stavins, 2010). Given the assumption that a high CSP score is positively connected in undertaking costs towards this direction (Barnett and Salomon 2012, 2006), only a considerable amount of investment and therefore achievement regarding CSP shall trigger the positive consumers' reactions which in turn will lead to a positive CSP-CFP relationship. Regarding the control variables, the Crisis dummy and the lagged dependent variables, the results for the quadratic models are similar with those of the linear models.

We further our analysis focusing on the three sub-components of the ESG disclosure score. Table 6 reports the empirical findings. Once again the first three specification concern 
the linear relationship between CFP and the three components (see, specifications (7)-(9)), whereas the latter three specifications focus on the quadratic relationship (i.e. (10)-(12)).

\section{[TABLE 6 HERE]}

The linear models do not allow us to report any significant relationship (either in the contemporaneous or lagged terms) between CFP and the three sub-components (i.e., ENV, SOC and GOV), suggesting that Hypotheses 2-4 cannot be confirmed. In addition, we include two interaction terms that allows us to capture whether GOV may indirectly impact firm performance via the $E N V$ and $S O C$ activities. Nevertheless, we cannot find any significant relationship suggesting that GOV does not have any direct or indirect effects on firm performance. Furthermore, we observe that both the signs and the significance of the control variables coefficients, the Crisis dummy coefficient and the lagged dependent variables are similar with Table 5.

However, turning to the quadratic models, the GOV score can be identified as the main driver of the relationship observed in Table 5, specifications (4)-(6). To elaborate further, we observe that for all accounting-based measures of CFP (i.e. $R o C$ and $R o A$ ) one can detect a U-shaped relationship between the GOV score and CFP, providing further evidence in favour of Hypothesis 5. This result is in line with a recent strand in the literature, which suggests that strategic investment in CSR-oriented governance structures shall improve the overall financial performance of the firm.

To elaborate further, the rationale behind the contribution of the GOV score to firm's CFP can be explained by using Stakeholder Influence Capacity (SIC) as introduced by Barnett (2007) via both supply and demand analysis. First, regarding the supply side, a CSR oriented governance structure affects the operation of the firm towards CSR oriented activities, including environmental and social related activities. Consequently, it allows for targeted CSR activities throughout the value chain of the firm that can also serve the "shared 
value" (Porter and Kramer, 2011, p.4) approach to CSR and therefore the financial performance of the firm (see, inter alia, McWilliams and Siegel, 2011; Bagnoli and Watts, 2003; Baron, 2001). In addition, CSR activities that belong to the $S O C$ score are often related to lump sum payments connected to "corporate philanthropy" which in turn may not affect the financial performance of the firms (Porter and Kramer, 2002). Second, on the demand side, CSR-oriented governance acts as a credible signal for long run commitment to CSR values. This enhances the positive demand effects from socially conscious consumers and therefore the financial performance of the firm (See for instance, Lambertini, L. and Tampieri, 2015; Becchetti et al. 2014; Manasakis et al., 2014; Kopel and Brand, 2012).

Interestingly enough, we cannot report any link between CSP and Ex. Stock Returns. This can be explained by the fact that tests based on excess stock market returns might be rather weak if CSR policies change only slightly over time (Gregory and Whittaker, 2013).The fact that CSP exercises an impact on accounting-based measures of CFP but not on Ex. Stock Returns may suggests that there is a positive demand effect from CSR activities on firms' revenues. Nevertheless, this effect may not be translated into higher excess stock returns, given that stock returns are affected by multiple other factors, as well.

Finally, when it comes to control variables, Risk and $R \& D$ expenditure have a significant effect; although not in the same direction (i.e. risk once again is reported to exercise a negative effect on CFP, whereas the reverse effect is exercised by $R \& D$ expenditure). Overall, the signs of the coefficients remain unchanged, regardless the specification. Once again, the Crisis dummy variable is negative and significant.

\section{Concluding remarks}

The present paper investigates relationship between corporate social performance and corporate financial performance, making use of a new CSR proxy, the Bloomberg ESG 
Disclosure score. In addition, we also consider the three sub-components of the ESG score (i.e. $E N V, S O C$ and $G O V$ ). We measure CFP using two accounting-based measures, i.e. $R o C$ and $R o A$, as well as, a market-based measure, that of Ex. Stock Returns. Our control variables include Sales, Risk and $R \& D$ expenditure. Our sample includes all firms that are listed in the S\&P500 stock market index. Annual data are considered for the period of 2007 to 2011.

Results from the linear model suggest that no significant relationships can be reported between CSP and RoA, RoC and Ex. Stock Returns. Notably, our analysis provides evidence of a U-shaped relationship between CSR performance and accounting-based CFP. This relationship implies that CSR pays off only after a certain threshold amount of investments and achievements regarding CSP have been made. Before this point is reached, additional CSR expenditures decrease CFP. Most prominent among our results is the fact that when we disaggregate the composite CSR score into its three sub-components we find that the governance sub-component is the main mechanism by which CSR commitment is translated into improved CFP. This result adds on the discussion regarding the StakeholderInfluence Capacity and confirms recent advances in theoretical literature which suggest that CSR oriented governance leads to positive effects on CFP.

Overall, companies use CSR as a part of their strategic planning in order to create additional value for their product. Effective CSR strategies can attract stakeholders, such as socially conscious consumers and investors, to increase their willingness to buy and invest, respectively. An immediate managerial implication of our findings suggests that in order for CSR to serve the interests of the shareholders a long-run planning and considerable resources should be dedicated at this direction, given that CSR expenditure does not pay off immediately, but only after a threshold of CSP has been reached. Furthermore, the fact that governance is the key driver affecting the CSP-CFP relationship suggests that CSR investments should be directed to this component. CSR dedicated governance can benefit the 
firm by both integrating CSR activities into firm's value chain in the direction of value creation and by acting as a signaling device to stakeholders regarding the commitment of the firm to CSR.

One of the main limitations of this study is that the ESG score does not take into account the kind of CSR a firm engages in. As Baron (2001) outlined in theory and Hillman and Keim (2001) confirmed empirically, different types of CSR (altruistic vs. strategic CSR) can have a very different effect on profitability. When those two different types of CSR are aggregated into one single score, the respective effects might cancel each other out understating the actual effect. Nevertheless, such drawback is shared with many other measurements of corporate social responsibility.

An interesting avenue for further research is the examination of the effects of ESG scores for other firms, such firms listed in Europe or Asia (in order to account for the effects of different regulatory frameworks) or among different industrial sectors, which will allow for fruitful comparisons. Furthermore, it would be interesting for future research to examine the direction of causality between CSP and CFP. Future work could also investigate the CSPCFP relationship using time-varying measures in order to examine its dynamic character.Finally, replicating the results using the KLD data would be a worthwhile consideration in order to establish the amount of variance in the results that is due to the different measures of CSR.

\section{References}

Andersen, M. L. and Dejoy, J.S. (2011). Corporate social and financial performance: The role of size, industry, risk, rand and advertising expenses as control variables. Business and Society Review 116 (2), 237-256.

Bagnoli, M, and Watts, S.G. (2003).Selling to socially responsible consumers: competition and the private provision of public goods.Journal of Economics and Management Strategy 12, 419-445. 
Barnea, A. and Rubin, A. (2010).Corporate social responsibility as a conflict between shareholders.Journal of Business Ethics 97, 71-86.

Barnett ML. (2007). Stakeholder influence capacity andthe variability of financial returns to corporate socialresponsibility. Academy of Management Review 32(3), 794-816.

Barnett, M.L, \& Salomon R.M. (2006).Beyond dichotomy: the curvilinear relationship between social responsibility and financial performance. Strategic Management Journal $27,1101-1122$.

Barnett, M.L, \& Salomon R.M. (2012).Does it pay to be really good? Addressing the shape of the relationship between social and financial performance.Strategic Management Journal 33, 1304-1320.

Baron, D.P. (2001).Private politics, corporate social responsibility, and integrated strategy.Journal of Economics and Management Strategy 10 (1), 7-45.

Becchetti, L., ArsenPalestini, A., NazariaSolferino, N.\&Tessitore M.E. (2014). The socially responsible choice in a duopolistic market: A dynamic model of "ethical product" differentiation. Economic Modelling 43, 114-123.

Becchetti, L. and Ciciretti, R. (2006).Corporate social responsibility and stock market performance. CEIS Tor Vergata.Research Paper Series, 27 (79).

Bloomberg (2013). Bloomberg 2012 Sustainability Report.

http://www.bloomberg.com/bsustainable/content/themes/sustainability/report/Bloomber gSustReport2012.pdf. (Retrieved May 11, 2014)

Brammer, S., Brooks, C. and Pavelin, S. (2009). The stock performance of America's 100 best corporate citizens. The Quarterly Review of Economics and Finance 49, 10651080 .

Callan, S. J. and Thomas, J. M. (2009).Corporate financial performance and corporate social performance: an update and reinvestigation. Corporate Social Responsibility and Environmental Management 16, 61-78.

Cochran, P. L. (2007). The evolution of corporate social responsibility.Business Horizons, $50.449-454$.

Eccles, R.G., Krzus M.P. \&Serafeim, G. (2011).Market Interest in Nonfinancial Information.Working Paper 12-018, Harvard Business School.

Economist (The) (2009 May, 16). A stress test for good intentions.Corporate social responsibility. 
Ellis, L. and Bastin, C. (2011). Corporate social responsibility in times of recession: changing discourses and implications for policy and practice. Corporate Social Responsibility and Environmental Management 18, 294-305.

European Commission. (2001). Promoting a European framework for corporate social responsibility. Luxembourg: Office for Official Publications of the European Communities.

Fernández-FeijóoSouto ,Belén (2009). Crisis and corporate social responsibility: threat or opportunity. International Journal of Economic Sciences and Applied Research 2(1), $36-50$.

Freeman, R.E. (1984). Strategic management: a stakeholder approach. London: Pitman.

Friedman, M. (1970, September 13). The Social Responsibility of Business is to Increase its Profits. New York Times Magazine.

García-Gallego A, Georgantzis N. 2009. Market eđects of changes in consumers' socialresponsibility. Journal of Economics and Management Strategy 19, 235-262.

Greening, D. W. and Turban, D.B. (2000).Corporate social performance as a competitive advantage in attracting a quality workforce.Business and Society 39 (3), 254-280.

Gregory, A. and Whittaker, J. (2013).Exploring the valuation of corporate social responsibility - a comparison of research methods. Journal of Business Ethics 116,120.

Harwood, I., Humbly, S. and Harwood, A. (2011). On the resilience of corporate social responsibility.European Management Journal 29(4), 283-290.

Heal, G. (2005). Corporate social responsibility: an economic and financial framework. The Geneva Papers 30, 387-409.

Hillman, A.M. and Keim, G. D. (2001).Shareholder value, stockholder management, and social issues: what's the bottom line? Strategic Management Journal 22, 125-139.

Jensen, M. C. (2001). Value maximization, stakeholder theory, and the corporate objective function. European Financial Management, 7 (3).297-317.

Jiao, Y. (2010).Stakeholder welfare and firm value.Journal of Banking and Finance, 34. 2549-2561.

Kopel, Michael \& Brand, Björn, (2012).Socially responsible firms and endogenous choice of strategic incentives, Economic Modelling 29(3), 982-989.

Lambertini, L. \&Tampieri A. (2015) Incentives, performance and desirability of socially responsible firms in a Cournot oligopoly. Economic Modelling 50, 40-48. 
Manasakis, C., Mitrokostas, E. and Petrakis, E. (2013).Certification of corporate social responsibility activities in oligopolistic markets.Canadian Journal of Economics 46 (1), 282-309.

Manasakis, C., Mitrokostas, E. and Petrakis, E. (2014).Strategic corporate social responsibility activities and corporate governance in imperfectly competitive markets.Managerial and Decision Econonomics 35 (7), 460-473.

Margolis, J. D., Elfenbein, H. A., and Walsh, J. P. (2009). Does it pay to be good? A metaanalysis and redirection of research on the relationship between corporate social and financial performance.Available atSSRN: http://ssrn.com/abstract=1866371

McWilliams, A. and Siegel, D. S. (2000).Corporate social responsibility and financial performance: correlation or misspecification?.Strategic Management Journal 21, 603609.

McWilliams, A. and Siegel, D. S. (2011). Creating and capturing value: strategic corporate social responsibility, resource-based theory, and sustainable competitive advantage. Journal of Management 37 (5), 1480-1495.

McWiliams, A., Siegel, D. S., and Wright, P.M. (2006).Corporate social responsibility: strategic implications. Journal of Management Studies 43 (1), 1-18.

Mittal, R.K., Sinha, N., Singh, A. (2008). An analysis of linkage between economic value added and corporate social responsibility. Management Decision 46 (9), 1437 - 1443.

Porter, M.E. and Kramer, M.R. (2002). The competitive advantage of corporate philanthropy.Harvard Business Review, 80 (12). 56-69.

Porter, M.E. and Kramer, M.R. (2011).Creating shared value.How to reinvent capitalismand unleash a wave of innovation and growth.Harvard Business Review, Jan-Feb 2011.

Portney, P. R. (2008). The (not so) new corporate social responsibility: an empirical perspective. Review of Environmental Economics and Policy 2 (2), 261-275.

Reinhardt, F.L. and Stavins, R. N. (2010).Corporate social responsibility, business strategy, and the environment.Oxford Review of Economic Policy. 26 (2), 164-181

Reinhardt, F.L., Stavins, R. N. and Vietor, H.K. (2008).Corporate social responsibility through an economic lens.Review of Environmental Economics and Policy 2 (2), 219239.

Russo, M. V. and Fouts, P. A. (1997).A resource-based perspective on corporate environmental performance and profitability.Academy of Management Journal 40 (3), 534-559. 
Schreck, P. (2011). Reviewing the business case for corporate social responsibility: new evidence and analysis.Journal of Business Ethics 103, 167-188.

Waddock, S A. and Graves B. S. (1997). The corporate social performance-financial performance link.Strategic Management Journal 18 (4), 303-319. 


\section{TABLES}

Table 1. Descriptive statistics of the variables under investigation. The sample period runs from 2007-2011.

\begin{tabular}{|c|c|c|c|c|c|}
\hline Variable & Obs & Mean & Std. Deviation & Min & Max \\
\hline$E S G$ & 2365 & 25.161 & 14.032 & 6.198 & 85.123 \\
\hline$E N V$ & 1432 & 23.976 & 17.131 & 0.775 & 89.922 \\
\hline$S O C$ & 2346 & 19.161 & 17.622 & 3.125 & 83.333 \\
\hline GOV & 2364 & 55.117 & 6.132 & 17.857 & 85.714 \\
\hline RoA & 2448 & 6.639 & 8.122 & -68.615 & 46.705 \\
\hline$R o C$ & 2149 & 13.976 & 14.641 & -107.571 & 250.897 \\
\hline $\begin{array}{l}\text { Ex. Stock } \\
\text { Returns }\end{array}$ & 2331 & 6.553 & 48.216 & -97.397 & 792.363 \\
\hline Risk & 2465 & 23.869 & 17.701 & 0.000 & 156.235 \\
\hline Sales & 2479 & 18096.8 & 35022.771 & 72.041 & 433526.000 \\
\hline$R \& D$ & 1426 & 612.137 & 1336.132 & 0.000 & 10991.000 \\
\hline \multicolumn{6}{|c|}{$\begin{array}{l}\text { Note: The variables are ESG }=\text { ESG disclosure score, ENV = environmental } \\
\text { disclosure score, } \mathrm{SOC}=\text { social disclosure score, GOV }=\text { governmental disclosure } \\
\text { score, RoA }=\text { return on assets, RoC }=\text { return on capital, Ex. Stock Returns }=\text { excess } \\
\text { stock market returns, Risk }=\text { leverage (as proxy for risk), Sales = sales revenue, R\&D } \\
=\text { Research \& Development expenditure. } \\
\text { Data source: } \text { Bloomberg }\end{array}$} \\
\hline
\end{tabular}




\begin{tabular}{|c|c|c|c|c|c|c|c|c|c|c|}
\hline & RoA & $\mathrm{RoC}$ & $\begin{array}{l}\text { Ex. Stock } \\
\text { Returns } \\
\end{array}$ & ESG & ENV & SOC & GOV & Risk & Sales & $R \& D$ \\
\hline RoA & 1.0000 & & & & & & & & & \\
\hline $\mathrm{RoC}$ & 0.7452 & 1.0000 & & & & & & & & \\
\hline Ex. Stock Returns & 0.0190 & $0.03-2$ & 1.0000 & & & & & & & \\
\hline ESG & 0.1056 & 0.0806 & 0.0136 & 1.0000 & & & & & & \\
\hline ENV & 0.0877 & 0.0462 & 0.0288 & 0.9970 & 1.0000 & & & & & \\
\hline SOC & 0.1045 & 0.1520 & 0.0186 & 0.9001 & 0.6956 & 1.0000 & & & & \\
\hline GOV & 0.1593 & 0.0462 & -0.0049 & 0.7858 & 0.6116 & 0.6056 & 1.0000 & & & \\
\hline Risk & -0.0941 & -0.1656 & -0.0157 & 0.2540 & 0.2367 & 0.2296 & 0.2730 & 1.0000 & & \\
\hline Sales & -0.0868 & 0.0144 & -0.0502 & -0.0556 & -0.0926 & 0.0367 & -0.0427 & -0.1586 & 1.0000 & \\
\hline R\&D & 0.3035 & 0.1576 & -0.0324 & 0.2947 & 0.2806 & 0.2894 & 0.2094 & -0.1900 & 0.3793 & 1.0000 \\
\hline
\end{tabular}

Note: The variables are $\mathrm{ESG}=\mathrm{ESG}$ disclosure score, $\mathrm{ENV}=$ environmental disclosure score, $\mathrm{SOC}=$ social disclosure score, $\mathrm{GOV}=$ governmental disclosure score, $\mathrm{RoA}=$ return on assets, $\mathrm{RoC}=$ return on capital, Ex. Stock Returns $=$ excess stock market returns, Risk $=$ leverage as proxy for risk, Sales $=$ sales revenue, $R \& D=$ Research $\&$ Development expenditure.

Data source: Bloomberg 
Table 3. ESG Disclosure Score. The sample period runs from 20072011.

\begin{tabular}{llrrrr}
\hline Year & Obs & Mean & Std. Deviation & Min & Max \\
\hline 2007 & 428 & 22.315 & 11.820 & 6.198 & 61.157 \\
2008 & 479 & 23.749 & 12.972 & 8.612 & 67.543 \\
2009 & 486 & 25.661 & 14.643 & 9.504 & 78.099 \\
2010 & 490 & 26.924 & 14.407 & 8.677 & 77.593 \\
2011 & 482 & 26.796 & 15.295 & 7.851 & 85.123 \\
\hline Data source: Bloomberg & & & & \\
\hline
\end{tabular}


Table 4. ENV, SOC and GOV Disclosure Score. The sample period runs from 2007-2011.

\begin{tabular}{|c|c|c|c|c|c|c|}
\hline Variable & Year & Obs & Mean & Std. Deviation & Min & Max \\
\hline ENV & 2007 & 229 & 20.811 & 14.741 & 0.775 & 61.607 \\
\hline ENV & 2008 & 280 & 22.159 & 15.999 & 0.775 & 66.666 \\
\hline ENV & 2009 & 288 & 25.943 & 17.722 & 0.775 & 78.512 \\
\hline ENV & 2010 & 325 & 24.827 & 17.219 & 0.775 & 78.512 \\
\hline ENV & 2011 & 310 & 25.239 & 18.668 & 1.379 & 89.922 \\
\hline SOC & 2007 & 426 & 15.686 & 15.689 & 3.125 & 68.750 \\
\hline SOC & 2008 & 478 & 17.060 & 16.712 & 3.125 & 73.438 \\
\hline SOC & 2009 & 484 & 19.326 & 18.044 & 3.125 & 82.456 \\
\hline SOC & 2010 & 484 & 21.539 & 17.801 & 3.125 & 81.250 \\
\hline $\mathrm{SOC}$ & 2011 & 474 & 21.808 & 18.776 & 3.125 & 83.333 \\
\hline GOV & 2007 & 428 & 54.064 & 5.453 & 21.429 & 75.000 \\
\hline GOV & 2008 & 479 & 54.585 & 5.715 & 23.214 & 76.786 \\
\hline GOV & 2009 & 486 & 55.159 & 6.192 & 17.857 & 82.142 \\
\hline GOV & 2010 & 489 & 55.893 & 6.390 & 33.929 & 82.143 \\
\hline GOV & 2011 & 482 & 55.754 & 6.596 & 33.929 & 85.714 \\
\hline
\end{tabular}


Table 5. CSP-CFP Relationship in Linear and Quadratic Models (ESG Composite Score). The sample period runs from 2007-2011.

\begin{tabular}{|c|c|c|c|c|c|c|}
\hline $\begin{array}{l}\text { Independent } \\
\text { Variable }\end{array}$ & $\begin{array}{r}(1) \\
\operatorname{RoA}\end{array}$ & $\begin{array}{r}(2) \\
\text { RoC }\end{array}$ & $\begin{array}{r}(3) \\
\text { Ex. Stock } \\
\text { Returns }\end{array}$ & $\begin{array}{r}(4) \\
\text { RoA }\end{array}$ & $\begin{array}{r}(5) \\
\text { RoC }\end{array}$ & $\begin{array}{r}(6) \\
\text { Ex. Stock } \\
\text { Returns }\end{array}$ \\
\hline$E S G_{t}$ & $\begin{array}{r}0.0171 \\
(0.600)\end{array}$ & $\begin{array}{r}0.0424 \\
(0.348)\end{array}$ & $\begin{array}{r}-0.0780 \\
(0.702)\end{array}$ & $\begin{array}{r}-0.0208^{*} \\
(0.082)\end{array}$ & $\begin{array}{r}-0.0294^{* *} \\
(0.028)\end{array}$ & $\begin{array}{r}-0.356 \\
(0.569)\end{array}$ \\
\hline$E S G_{t}{ }^{2}$ & & & & $\begin{array}{r}0.0042 * \\
(0.097)\end{array}$ & $\begin{array}{r}0.00102 * \\
(0.070)\end{array}$ & $\begin{array}{r}0.00424 \\
(0.612)\end{array}$ \\
\hline Risk $_{t}$ & $\begin{array}{r}-0.232 * * * \\
(0.000)\end{array}$ & $\begin{array}{r}-0.141^{* * *} \\
(0.000)\end{array}$ & $\begin{array}{r}-1.362^{* * * *} \\
(0.000)\end{array}$ & $\begin{array}{r}-0.232 * * * \\
(0.000)\end{array}$ & $\begin{array}{r}-0.140 * * * \\
(0.000)\end{array}$ & $\begin{array}{r}-1.354 * * * \\
(0.000)\end{array}$ \\
\hline Sales $_{t}$ & $\begin{array}{r}0.000040^{*} \\
(0.069)\end{array}$ & $\begin{array}{r}0.000092^{* * * *} \\
(0.003)\end{array}$ & $\begin{array}{r}-0.000044 \\
(0.748)\end{array}$ & $\begin{array}{r}0.000040^{*} \\
(0.069)\end{array}$ & $\begin{array}{r}0.000092 * * * \\
(0.003)\end{array}$ & $\begin{array}{r}-0.0000450 \\
(0.740)\end{array}$ \\
\hline$R \& D_{t}$ & $\begin{array}{r}-0.00069 \\
(0.354)\end{array}$ & $\begin{array}{r}0.00231 * * \\
(0.032)\end{array}$ & $\begin{array}{r}0.0157 * * * \\
(0.001)\end{array}$ & $\begin{array}{r}0.00073 \\
(0.322)\end{array}$ & $\begin{array}{r}0.00232 * * \\
(0.031)\end{array}$ & $\begin{array}{r}0.0159 * * * \\
(0.001)\end{array}$ \\
\hline Crisis $_{t}$ & $\begin{array}{r}-2.562 * * * \\
(0.000)\end{array}$ & $\begin{array}{r}-1.850^{* * *} \\
(0.004)\end{array}$ & $\begin{array}{r}-13.82 * * * \\
(0.000)\end{array}$ & $\begin{array}{r}-2.561 * * * \\
(0.000)\end{array}$ & $\begin{array}{r}-1.856 * * * \\
(0.004)\end{array}$ & $\begin{array}{r}-13.86^{* * *} \\
(0.000)\end{array}$ \\
\hline $\operatorname{RoA} A_{t-1}$ & $\begin{array}{r}0.486^{* * * *} \\
(0.000)\end{array}$ & & & $\begin{array}{r}0.485^{* * * *} \\
(0.000)\end{array}$ & & \\
\hline$R o C_{t-1}$ & & $\begin{array}{r}0.604 * * * \\
(0.000)\end{array}$ & & & $\begin{array}{r}0.603 * * * \\
(0.000)\end{array}$ & \\
\hline ExReturns $_{t-1}$ & & & $\begin{array}{r}-0.241^{* * *} \\
(0.000)\end{array}$ & & & $\begin{array}{r}-0.241^{* * *} \\
(0.000)\end{array}$ \\
\hline$E S G_{t-1}$ & $\begin{array}{r}-0.0243 \\
(0.488)\end{array}$ & $\begin{array}{r}-0.0593 \\
(0.223)\end{array}$ & $\begin{array}{r}-0.0152 \\
(0.945)\end{array}$ & & & \\
\hline Constant & $\begin{array}{r}6.464 * * * \\
(0.000)\end{array}$ & $\begin{array}{r}7.990 * * * \\
(0.000)\end{array}$ & $\begin{array}{r}24.19^{* * * *} \\
(0.000)\end{array}$ & $\begin{array}{r}7.813 * * * \\
(0.000)\end{array}$ & $\begin{array}{r}8.494 * * * \\
(0.000)\end{array}$ & $\begin{array}{r}31.42 * * * \\
(0.000)\end{array}$ \\
\hline Observations & 1016 & 806 & 952 & 1016 & 806 & 952 \\
\hline R-Squared & 0.3538 & 0.6042 & 0.1066 & 0.3551 & 0.6043 & 0.1086 \\
\hline \multicolumn{7}{|c|}{$\begin{array}{l}\text { Note: } \text { The variables are ESG }=\text { ESG disclosure score, } \mathrm{RoA}=\text { return on assets, } \mathrm{RoC}=\text { return on capital, Ex. Stock } \\
\text { Returns }=\text { excess stock market returns, Risk }=\text { leverage as proxy for risk, Sales }=\text { sales revenue, } \mathrm{R} \& \mathrm{D}=\text { Research } \& \\
\text { Development expenditure, Crisis }=\text { dummy variable for financial crisis. } \\
\text { P-values in parentheses: } * \mathrm{p}<0.1, * * \mathrm{p}<0.05, * * * \mathrm{p}<0.01 \\
\text { Data source: Bloomberg }\end{array}$} \\
\hline
\end{tabular}


Table 6. CSP-CFP Relationship in Linear and Quadratic Models (ESG sub-components scores). The sample period runs from 2007-2011.

\begin{tabular}{|c|c|c|c|c|c|c|}
\hline $\begin{array}{l}\text { Independent } \\
\text { Variable }\end{array}$ & $\begin{array}{r}(7) \\
\text { RoA }\end{array}$ & $\begin{array}{r}(8) \\
\mathrm{RoC}\end{array}$ & $\begin{array}{r}(9) \\
\text { Ex. Stock } \\
\text { Returns }\end{array}$ & $\begin{array}{l}(10) \\
\text { RoA }\end{array}$ & $\begin{array}{l}(11) \\
\text { RoC }\end{array}$ & $\begin{array}{r}(12) \\
\text { Ex. Stock } \\
\text { Returns }\end{array}$ \\
\hline$E N V_{t}$ & $\begin{array}{r}0.0176 \\
(0.931)\end{array}$ & $\begin{array}{r}0.229 \\
(0.395)\end{array}$ & $\begin{array}{l}0.0696 \\
(0.961)\end{array}$ & $\begin{array}{r}-0.00512 \\
(0.934)\end{array}$ & $\begin{array}{r}0.101 \\
(0.224)\end{array}$ & $\begin{array}{r}-0.679 \\
(0.113)\end{array}$ \\
\hline$E N V_{t}{ }^{2}$ & & & & $\begin{array}{r}-0.000106 \\
(0.902)\end{array}$ & $\begin{array}{r}-0.00106 \\
(0.345)\end{array}$ & $\begin{array}{r}0.0102 * \\
(0.085)\end{array}$ \\
\hline $\mathrm{SOC}_{t}$ & $\begin{array}{r}0.0623 \\
(0.773)\end{array}$ & $\begin{array}{r}-0.223 \\
(0.449)\end{array}$ & $\begin{array}{r}-0.240 \\
(0.874)\end{array}$ & $\begin{array}{r}-0.0249 \\
(0.716)\end{array}$ & $\begin{array}{l}0.0681 \\
(0.459)\end{array}$ & $\begin{array}{r}-0.0533 \\
(0.911)\end{array}$ \\
\hline $\mathrm{SOC}_{t}{ }^{2}$ & & & & $\begin{array}{r}0.000356 \\
(0.694)\end{array}$ & $\begin{array}{r}-0.00116 \\
(0.325)\end{array}$ & $\begin{array}{r}-0.00104 \\
(0.869)\end{array}$ \\
\hline$G O V_{t}$ & $\begin{array}{r}0.122 \\
(0.326)\end{array}$ & $\begin{array}{c}0.0238 \\
(0.885)\end{array}$ & $\begin{array}{r}0.217 \\
(0.811)\end{array}$ & $\begin{array}{r}-0.224 * \\
(0.099)\end{array}$ & $\begin{array}{r}-1.622 * * \\
(0.031)\end{array}$ & $\begin{array}{r}2.103 \\
(0.599)\end{array}$ \\
\hline $\mathrm{GOV}_{t}{ }^{2}$ & & & & $\begin{array}{r}0.00232 * * \\
(0.019)\end{array}$ & $\begin{array}{r}0.0136^{* *} \\
(0.026)\end{array}$ & $\begin{array}{r}-0.0161 \\
(0.618)\end{array}$ \\
\hline$G O V x E N V_{t}$ & $\begin{array}{r}-0.000403 \\
(0.906)\end{array}$ & $\begin{array}{r}-0.00319 \\
(0.476)\end{array}$ & $\begin{array}{r}-0.00138 \\
(0.954)\end{array}$ & & & \\
\hline $\mathrm{GOVxSOC}_{t}$ & $\begin{array}{r}-0.00109 \\
(0.765)\end{array}$ & $\begin{array}{r}0.00356 \\
(0.469)\end{array}$ & $\begin{array}{r}0.00196 \\
(0.939)\end{array}$ & & & \\
\hline Risk $_{t}$ & $\begin{array}{r}-0.428 * * * \\
(0.000)\end{array}$ & $\begin{array}{r}-0.345^{* * *} \\
(0.000)\end{array}$ & $\begin{array}{r}-1.778^{* * *} \\
(0.000)\end{array}$ & $\begin{array}{r}-0.420 * * * \\
(0.000)\end{array}$ & $\begin{array}{r}-0.345^{* * *} \\
(0.000)\end{array}$ & $\begin{array}{r}-1.741^{* * *} \\
(0.000)\end{array}$ \\
\hline Sales $_{t}$ & $\begin{array}{r}0.00003 * \\
(0.061)\end{array}$ & $\begin{array}{r}0.00008^{* * *} \\
(0.001)\end{array}$ & $\begin{array}{r}-0.000009 \\
(0.943)\end{array}$ & $\begin{array}{r}0.00003^{*} \\
(0.055)\end{array}$ & $\begin{array}{r}0.00008^{* * *} \\
(0.001)\end{array}$ & $\begin{array}{r}-0.00001 \\
(0.897)\end{array}$ \\
\hline$R \& D_{t}$ & $\begin{array}{r}0.00007 \\
(0.911)\end{array}$ & $\begin{array}{r}0.00180^{*} \\
(0.050)\end{array}$ & $\begin{array}{r}0.0147 * * * \\
(0.001)\end{array}$ & $\begin{array}{r}0.00002 \\
(0.976)\end{array}$ & $\begin{array}{r}0.00169^{*} \\
(0.065)\end{array}$ & $\begin{array}{r}0.0150 * * * \\
(0.001)\end{array}$ \\
\hline Crisis $_{t}$ & $\begin{array}{r}-1.928 * * * \\
(0.000)\end{array}$ & $\begin{array}{r}-0.812 \\
(0.241)\end{array}$ & $\begin{array}{r}-8.218^{* *} \\
(0.031)\end{array}$ & $\begin{array}{r}-1.950 * * * \\
(0.000)\end{array}$ & $\begin{array}{l}-0.864 \\
(0.210)\end{array}$ & $\begin{array}{r}-8.281 * * \\
(0.029)\end{array}$ \\
\hline $\operatorname{Ro} A_{t-1}$ & $\begin{array}{r}0.459 * * * \\
(0.000)\end{array}$ & & & $\begin{array}{r}0.459 * * * \\
(0.000)\end{array}$ & & \\
\hline$R o C_{t-1}$ & & $\begin{array}{r}0.505 * * * \\
(0.000)\end{array}$ & & & $\begin{array}{r}0.505 * * * \\
(0.000)\end{array}$ & \\
\hline $\begin{array}{l}\text { Ex. Stock } \\
\text { Returns }_{t-1}\end{array}$ & & & $\begin{array}{r}-0.199 * * * \\
(0.000)\end{array}$ & & & $\begin{array}{r}-0.199 * * * \\
(0.000)\end{array}$ \\
\hline
\end{tabular}




\begin{tabular}{lrrrrrr} 
ENV & -0.163 & -0.422 & -1.559 & & & \\
& $(0.434)$ & $(0.123)$ & $(0.305)$ & & \\
SOC $_{t-1}$ & -0.138 & 0.312 & 0.684 & & \\
& $(0.520)$ & $(0.278)$ & $(0.646)$ & & \\
GOV & & & & \\
& $-0.208^{*}$ & -0.117 & -0.388 & & & \\
& $(0.070)$ & $(0.432)$ & $(0.676)$ & & & \\
GOVxENV & 0.00287 & 0.00643 & 0.0291 & & & \\
& $(0.414)$ & $(0.159)$ & $(0.255)$ & & & \\
GOVxSOC & 0.00234 & -0.00475 & -0.0138 & & & \\
& $(0.521)$ & $(0.328)$ & $(0.586)$ & & & \\
Constant & $11.07 *$ & $14.27 *$ & 24.94 & 13.16 & $58.87 * *$ & -56.89 \\
& $(0.079)$ & $(0.093)$ & $(0.586)$ & $(0.453)$ & $(0.010)$ & $(0.639)$ \\
\hline Observations & 611 & 494 & 574 & 611 & 494 & 574 \\
R-Squared & 0.3689 & 0.4905 & 0.1243 & 0.3657 & 0.4929 & 0.1267 \\
\hline
\end{tabular}

Note: The variables are ENV $=$ environmental disclosure score, $\mathrm{SOC}=$ social disclosure score, $\mathrm{GOV}=$ governmental disclosure score, $\mathrm{RoA}=$ return on assets, $\mathrm{RoC}=$ return on capital, Ex. Stock Returns $=$ excess stock market returns, Risk $=$ leverage as proxy for risk, Sales $=$ sales revenue, $R \& D=$ Research $\&$ Development expenditure, Crisis $=$ dummy variable for financial crisis p-values in parentheses: $* \mathrm{p}<0.1, * * \mathrm{p}<0.05, * * * \mathrm{p}<0.01$

Data source: Bloomberg 